\title{
Polemical Writings on the Sources of Sirah in the West: A critical Evaluation of Robert Spencer's Book Did Muhammad Exist.?
}

"Tariq Aziz

** Dr. Muhammad Shahbaz Manj

\section{ABSTRACT:}

Prophet Muhammad (PBUH) has inspired various scholars to write about his life, character, teachings and contributions to humanity. He is the only man in the whole world whose life, character, teachings and utterances have been completely recorded. Western writers also studied the life and teachings of the Prophet Muhammad (PBUH). Their study of the prophet has generally been motivated by hostile criticism and religious and historical prejudice of the west. Robert Spencer is also included in the list of such critics of Prophet Muhammad (PBUH). He is an American author who is very famous for his criticism of Islam, Qur'ān and Prophet of Islam. He has published fifteen books so far. Along with other aspects he criticizes sources of the Sirah of Prophet Muhammad (PBUH). This research evaluates the objections raised by Robert Spencer on the Qur'ān and Hadith as sources of Sirah. It, rejecting Spencer's objections, proves that Qur'ān and Hadith are the most authentic and reliable sources of Sirah and provide a lot of authentic information about the personality, deeds and teachings of the Holy Prophet (PBUH).

Key Words: Robert Spencer, Sources, Sirah, Qu'rān, Hadith.

\section{Introduction}

Western researchers and scholars of Islam have been used various dishonest approaches to dealing with Prophet Muhammad' life. These approaches are very old and exist since the beginning of time. Anyone who has read the Bible or the Qur'an will discover that one of the most common methods of dealing with people who have come as prophets in the name of God is to accuse them of evil, to discredit their status and personality, and to harm them without any remorse in the name of the grant and the so-called service to humanity. Watt says that the Prophet Muhammad is undoubtedly one of the most maligned historical figures in the world, where people compete for who can earn more money and more television programs that incite hatred and disagreement towards the man himself and his followers. People like Robert Spencer, Pipes, Sam Chamoun, and other old people such as John Damascene, Dante, distorted

"Research Scholar, Department of Islamic \& Arabic Studies, University of Sargodha. Email: prof.aziztariq@gmail.com

${ }^{* *}$ Assistant Professor, Department of Islamic \& Arabic Studies, University of Sargodha. 
the Prophet of Islam and portrayed Islam in a negative way in order to create hatred towards it and reject faith that was attractive to many people and gained many converts as it does today. Not only did they gain wealth in their own way, they also served as advisers to various government organizations and agencies that incite hatred and spread lies within societies that discriminate against Muslims. One of the reasons why these people have a lot of credibility and support is their ability to manipulate Islamic books such as Qur'ān, Hadith and biographical writings, citing information in our own sources, the basis of Islam. But in doing so, these people made the blunt mistakes and ignored traditional scholastic methods in dealing with such information. ${ }^{1}$

An American author, Robert Spencer, is very famed for his criticism of Islam, Qur'ān and Prophet of Islam. He has published number of books, articles and has delivered talks on the relevant subject. He constantly questions about Muhammad's historicity. He claims that the largest part of material we have in our hands about Muhammad is "legend, not historical fact." historical records, doesn't make it clear that "there was an Arab prophet named Muhammad anywhere near Mecca, who brought any kind of message to the world." 3 Records just prove "that if there was a Muhammad, he was not in Mecca and didn't preach anything that closely resembles Islam." 4

Along with other aspects he criticizes sources of the Sirah, particularly Qur'ān and Hadith. He claims that "Even the pillars used to support the traditional account begin to crumble upon close scrutiny."5 This paper aims at exploring and scholarly evaluating his ideas about Qur'ān and Hadith as sources of Sirah from the perspective of his book "Did Muhammad Exist? An inquiry into Islam's Obscure origin."

\section{Robert Spencer on Qur'ān as a Source of Sirah:}

Robert Spencer discussing Qur'ān as source of Sirah of Prophet Muhammad (Peace be upon him) has elevated two objections. One is about preservations of the Qur'ān and second about the accounts of the Qur'ān concerning Prophet of Islam. Here we discuss his objections, after giving the references from the above mentioned book.

\section{Preservation of Qur'ān:}

Robert Spencer, in his referred book, asserts that "Qur'an is not a collection of what Muhammad presented as revelations from the one true God."6 He, quoting Wansbrough argues that Quran basically was developed to determine Islam's root in Arab. 7 To him Muslim claim of unchanging Qur'ān is absurd. To establish this claim he has specified a whole chapter of his book with the title: "The Unchanging Qur'ān Changes." 
After this short depiction of Robert Spencer's idea about preservation of the Qur'ān, we explore the facts about such claims and real nature of the subject of preservation of the Quran.

The Quran, through the angel Gabriel, was revealed to the Prophet of Islam in Arabic language within twenty three years. It revealed variably in concise and long verse and Suras.8 Upon receiving God's words, Prophet conveyed the same to his companions by reading the same words of revelation. Cadenced mode of the Qur'ān facilitates the eloquent expression of its preservation, which is depicted by God as one of its indispensable individualities of conservation and remembering ${ }^{9}$, especially in the community, prided on writing long pieces of verses. Thus a large number of people saved the huge portions of revelation easily. ${ }^{10}$

Prophet ordered his companions to convey to the revealed verses to others. ${ }^{11}$ Muslim also read the Quran five times a day in their prayers. Many companyions exactly memorized the complete the Quran. ${ }^{12}$

Moreover, the arrangement of the Quran was also done by the prophet with which his companions were full familiar. ${ }^{13}$ In each Ramadan Quran was repeated by the prophet with angel Gabriel after in presence of his companions. ${ }^{14}$ During his death year, he read the Quran twice. Thus arrangement of chapters and verses in it, in a particular sequence was made by the prophet and known to his companions. The companions of the Prophet took these readings to countries they went, and taught them to their pupils and followers. ${ }^{15}$ The same Quran spread in the various territories of the earth.

Hifz Quran or its memorization is an incessant practice among the Muslim across the globe and since the centuries back to the time of prophet of Islam. This is the only book learnt by heart by millions of people. ${ }^{16}$ This fact leads the number of Western scholars to the conclusion that its text passed through the centuries in an established living order of devotion. ${ }^{17}$

The Quran was completely recorded in written form by Prophet's companions, like zaid ibn thabit, Ubay Ibn Kab, Ibn Masud, Abi Sufyan, Khalid Ibn Walid, Zubair Ibn Awām, in his time at the time of revelation. ${ }^{18}$ It was written on leather, parchments, bones and stalks of date palm.

After the battle of Yamama in 11of hijrah, on the martyrdom of a number of companions, under the fear of lost of Quran by losing of Huffaz of Quran, on the suggestion of Umer a board zaid ibn Sabit was appointed to collect the scattered Quran in to mushaf. Thus the complete Quran collected. ${ }^{19}$ The committee very accurately gathered the whole Quran which was written with the authority of the prophet. ${ }^{20}$ In the reign of third caliph, Usmān, after the fear of 
quarrel and dispute over variant readings of the Quran, allowed by the prophet, it was written down on the Qurayshi dialect. ${ }^{21}$

The above account of preservation of the Quran derived entirely from real traditions. Many orientalists themselves, like Gib, have acknowledged that it seems rational that there have been no change of material in the Quran and very accurately preserved as it was in Muhammad's time ${ }^{22}$ John Burton in his work on the Quran said, that the text of the contemporary Quran is same as was presented by Muhammad. ${ }^{23}$

\section{Robert Spencer on the Qur'ān as source of Sirah:}

To Muslims Qur'ān is a potential source of contemporary information about the life of Prophet Muhammad but Robert Spencer is of the view that it "reveals little about the life of Islam's central figure." 24 He argues that in the Qur'ān where prophets are mentioned many times name Muhammad appears only four times out of which three times it just has been used as a title like "praised one", "chosen one" and "nothing at all is disclosed about his life. It exposes that nothing can be collected "about Muhammad's biography...on the basis of Qur'ānic text alone." 25

These objections are baseless and show lack of knowledge of the writer about mode, methodology and fact about the criteria of the Qur'ānic accounts regarding Muhammad and other historical figures and narrations.

The Qur'ān is by all standards, historical, whether contextual, religious, nonreligious, most authentic document in the world. It is more genuine than any book of history, more real than any religious texts, is more authentic than any existing document. It is mutawatir in nature, meaning the quantity of people who have recorded it, learnt it by hearts and passed it on from different eras and different places with virtually no dissimilarity. Muslims follow a strict line in terms of seeking true knowledge and linking them. The Qur'ān is at the top of the pyramid, the most authentic document that tells the life of the Prophet of Islam. Anyone who wants to understand the biography must always refer to it. It contains statements about the life and activities of the Prophet in several ways, and contains the messages of the teachings of the band that handed it to mankind. In other words, the best thing about it is his role as Prophet and Messenger of Allah. The Koran also contains very clear references to certain events and incidents of his life, both public and private, to the etiquette of his receipt of the documents of God, and his role as preachers and carriers of the believers in this world, the Hereafter. It states the opposition of the infidels, the objections they raised and the responses given to their demands. The Qur'ān speaks of his sufferings that the Prophet (PBUH) encountered in order to call 
him. It mentions how polytheists accused him of practicing magic. The Qur'ān mentions the exodus of the Prophet (PBUH) and the most important battles he fought after his migration to Medina. There are references to his personal life prior to his Prophethood. The Qur'an refers to his childhood:

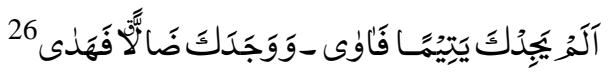

Did he not find you an orphan and protect you?

It also refers to his noble and sublime character:

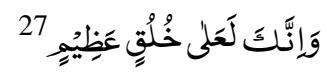

And lo! thou art of a tremendous nature.

The Quran mentions his early hour's poverty, his orphan hood and his affiliation with his wives. So he talks about a lot of events of the Prophet's life. There is no portion of the life of the Prophet and his message, which is not stated in the Qur'ân except for the specific dates of events and occasions. In fact, each part or piece of the part has been revealed on specific events and occurrences of the life of the prophet.

The Quran also hints at previous peoples and civilizations. It speaks of the position and destiny of the former incredulous peoples. All these provide the necessary basic information about the Prophet's life and mission. Because the Qur'ārn is the most strong book on earth, and it has been so strongly proven that no wise man doubts his texts and historical validity. The events of the Prophet's life there are unanimously considered the most correct sources of biography. Therefore, any information and glimpses of the life of the Prophet (PBUH) and his activities in the Qur'an must have unprecedented precedence over all other sources of information.

It should be noted, however, that the Qur'ān does not discuss the details of the Prophet's life (PBUH); rather it states them in general. When it talks about a battle, it does not tell us the reasons for it, or the number of Muslims and polytheists who fought or the number of idolaters killed or captured, it, rather talks about the lessons to be learned from the battle. This is the goal of the Quran in all the stories that tell us about the former prophets and the former nations. Hence, we can not rely solely on the texts of Quran that speak of Prophet's life, if we are to obtain a complete picture of the life of the Prophet as it is not the biography of the prophet. It nowhere claims that it speaks about the life history of Prophet of Islam.

\section{Robert Spencer on Hadith as a Source of Sirah:}

Robert Spencer claims that much of the details about Prophet Muhammad is clearly factionary in nature. According to him none of hadith collections "date 
from earlier than two centuries after Muhammad's death." Quoting Ignaz Goldziher, he says that hadiths were fabricated under different political and religious intentions. 28 Not only matns of the traditions but isnads are also unreliable as they were invented and forged much later. They apparently became mandatory in the early 700s - around the time of Abd al-Malik and Hajjaj ibn Yusuf, or shortly thereafter. ${ }^{29}$

Scholarly evaluation of these objections reveals them unfounded. Following points about different questions regarding hadith of the prophet prove that all doubts concerning the subject are groundless:

\section{Early Hādīth Criticism:}

Companions of the Prophet used to go to the Prophet to confirm the traditions they had heard. Professor Azami, referring to examples in the different hadith corpses says that if criticism is the effort to differentiate right from wrong, then undoubtedly it was started in prophet's life time. We see this type of examination or confirmation in Ali, Ibn Ka'ab, Abdullah bin Amir and Omar and Zainab wife of Ibn Masood and others. In others word it can be argued that criticism of hadith goes back to prophet's era. ${ }^{30}$

It is clear that this practice to verify reports directly by the Messenger of Allah had to stop with the death of the Prophet, and at that time the Companions of the prophet used to verify ahadīth with each other. Hazrat Omar, for instance, was strict in maintaining the correct spreading of the Hadith. In this regard example of Abu Musa Ashari can be read in Sahih Muslim. Omar intimidated to punish Abu Musa Ashari on failing to provide evidence on the incident he narrated before Hazrat Umar. Umar had no doubt regarding Abu Musa, but was only intended to maintain strict control over the transmission of the hadiths.

Several instances of this type can be presented. Abi Hurayrah, Aiysha, Omar and Ibn Umar can be seen verifying authenticity of the traditions. Sometimes they check the numbers through cross-references (as in the incident about Abu musa and Umer) and through "time series checks". Imam Muslim has reported that Aiysha listened a hadith by Abdullah bin Amr, after a year she sent her servant to Abdullah Ibn Amr to listen the hadith again from Abdullah bin Amr to ensure that whether he narrated it exactly as he listened from Prophet and did not commit any error regarding the account. ${ }^{31}$

We can summarize our discussion in with M.Z. Siddiqi's words that Ahāāith of Prophet Muhammad peace be upon him has been the topic of relentless quest and study throughout the Muslim since the dawn of the history of Islam to the present era. During Muhammad's lifetime, many Sahaba tried to acquire everything they heard from the Prophet and then conveyed these traditions to 
others, and repeat it within their circles. Some Sahaba wrote the traditions in the papers that later read to their families and their pupils and disciples. After the prophet's death, his companions spread in different states, they spread these ahādith in their relevant territories and cities. This conservation and dissemination of ahādith is unprecedented activity in the world history. ${ }^{32}$

It is now clear that Robert Spencer's objections are baseless. There is no evidence that he can confirm any case of fabrication of the statement of the Messenger of God (PBUH) from the time of his death until the beginning of the last third of the first century.

Muslim scholars developed the most meticulous testing schemes to deal with the level of originality to record what we call history. They were engaged in what is text and objectivity in criticism.

Criticism in the modern sense of Orientalism was only to weaken the encyclopaedia of enormous literature of hadith, where the criteria for separating sound and weak ahādith were based on criticism of content and chain. So, if there is a standard, they are the best way to correct it rather than to blame it.

\section{Authenticity of Isnād of Ahādith}

An important tool used to preserve ahādith is the system of isnād (attribution), which was developed inimitably by the Islamic Ummah. The scheme of attribution is the place where the source of its information is mentioned, and in turn the narrative follows the entire path to the Prophet (PBUH).

Abdullah al-Mubarak eloquently stated the importance of attribution, saying that "attribution is part of religion." If it's not about attribution, anyone will say what they want to say. ${ }^{33}$ Regarding the importance of attribution, Sufyan alThawri (d. 161) said: Isnād is the sword of Muslim, without which how can he fight! Through the Isnad, Muslim scholars eradicated the novelty that people tried to carry to Islam. According to some scholars: ahadith is religion, therefore, see from whom you are receiving your religion. ${ }^{34}$

According to Dr Hamidullah this system was more secure than the current publishing system. Even in more cautiously recorded work, there are number of problems that one cannot point out in the case of collecting and verifying the hadith literature. ${ }^{35}$

It can be said that attribution is a vital element of each hadith. Without Isnād no one can verify the authenticity of the tradition. Thus Isnād are not an ordinary thing, it has utmost importance in the science of hadith.

Another important point is that some of the early researchers did not mention their attribution. This does not mean they do not know the snail or they did not mean they did not know the bond or did not know it at another time. During the 
early years they did not see the need to always refer to attribution, and when theliars appeared, obviously the necessity was very clear.

\section{Criteria for the evaluation of Isnād:}

The N. Abbott, a well-known scholar of Prophet's tradition, elucidates how the development of these traditions has been the outcome of numerous correspondding chains of transmission? She demonstrate that these ahadith are reliable and a valid source of information of history. Ahādith of Prophet Muhammad as conveyed by his companions and successors, as a general rule, has been cautionusly confirmed at every step of the transmission. The so-called extraordinary development of ahâdith in the second and third centuries of Islam was not the development of content in the first place, Mohammed and the companions of the Companions, but it is largely a steady increase in parallel and multiple transmission chains. 36

In short, the attempt of Robert Spencer to study about ahāāith literature and sanad is based on the books in history, sirah and jurisprudence. He does not select accurate and real source of ahādīth for his studies. Therefore, the result became opposite of reality.

\section{Criteria of Knowing Fabrication in Matns:}

The Principles of acceptance of hadith provide a broad and vast scope for the methodology to identify the authenticity and weight of traditions of the prophet Muslim scholars have identified some limits to criticize content and to evaluate the methodology of hadith literature. Some of these principles are as under:

1. The tradition must not be contrary to other traditions already accepted by the authorities on this subject as reliable and stable. It should not contradict the text of the Qur'ān, or the mutawātir hadith, absolute consensus of society, or the established fundamental principles of Islam.

2. Hadith should not be against the disputation of reason, the laws of nature, or common sagacity.

3. Tradition setting up a very excessively high recompense for not worth mentioning good actions or excessively sever penalty for common sins, must be discarded.

4. Tradition mentioning the higher virtue of persons, clans, and meticulous places should normally be rejected.

5. Tradition holding such remarks of prophet (PBUH) as may not be a part of his prophetic vocation or such words as clearly inappropriate for him should be discarded.

6. A matn shouldn't defy the fundamental system of Arabic syntax and mode. ${ }^{37}$ 


\section{Conclusion:}

To Muslims Prophet Muhammad (Peace be upon him) is the only man in the whole world whose life, character, teachings and utterances have been completely recorded. In modern polemical writings about the sources of Sirh of Prophet Muhammda (Peace be upon him) in the West, it is argued that sources of Sirah particularly Qur'ā and Hadith sources of the same are not reliable. Robert Spencer, a prominent polemical American writer and orientalist has raised many objections about the mentioned sources of Sirah. This paper studies his ideas from the perspective of his book "Did Muhammad Exist: An Inquiry into Islam's Obscure Origin. It, rejecting Spencer's objections, proves that Qur'ān and Hadith are the most authentic and reliable sources of Sirah and provide a lot of information about the personality, deeds and teachings of the Holy Prophet. It proves the Qur'ān and hadith as sources of Sirah very authentic and reliable sources.

\section{REFRENCES:}

${ }^{1}$ Gabriel Keresztes and Muatassim Al Humaidi, The Main Sources of Seerah and the Correct Way of Approaching it

http://www.muslim-library.com/english/the-main-sources-of-seerah-and-the-correctway-of-approaching/

${ }^{2}$ Robert Spencer, Did Muhammad Exist?: An Inquiry Into Islam's Obscure Origins (New York : ISI Books, 2012),p-19

${ }^{3}$ Spencer, Did Muhammad Exist? P-193

${ }^{4}$ Spencer, Did Muhammad Exist? P-193

${ }^{5}$ Spencer, Did Muhammad Exist? P-196

${ }^{6}$ Spencer, Did Muhammad Exist? P-128

${ }^{7}$ Spencer, Did Muhammad Exist?, P-128

${ }^{8}$ Muhammad Hamidullah, Introduction to Islam,(London:MWH Publishers, 1979)P17

${ }^{9}$ See: Quran 44:58; 54:17,22,32,40

${ }^{10}$ See: Michael Zwettler, The Oral Tradition of Classical Arabic Poetry (Ohio State Press, 1978), P-14.

${ }^{11}$ Al-Bukhari, Al-Bukhari, No 546.

${ }^{12}$ See: Al-Bukhari, No.525.

${ }^{13}$ Ahmad von Denffer, Ulum al-Qur'an, (The Islamic Foundation, UK, 1983), P41-42

${ }^{14}$ See: Al-Bukhari, Hadith No.519

${ }^{15}$ Ibn Hisham, Seerah al-Nabi, (Cairo, n.d.,) Vol.1, P-199

${ }^{16}$ William Graham, Beyond the Written Word, (UK: Cambridge University Press, 1993), P-80.

${ }^{17}$ See: Kenneth Cragg, The Mind of the Qur'an, (London: George Allen \& Unwin, 1973), P-26. 
${ }^{18}$ Jalal al-Din Suyuti, Al-Itqan fi 'Ulum al-Qur'an, (Beirut: Maktab al-Thaqaafiyya, 1973), Vol.1, P41 \& 99.

${ }^{19}$ See: Al-Bukhari. Nos, $201 \&$ 509. Hadith No.301

${ }^{20}$ Ibn Hajar al-'Asqalani, Fath al-Bari, Vol.9, P10-11

${ }^{21}$ See: Al-Bukhari, No.510

${ }^{22}$ H.A.R. Gibb, Mohammedanism, (London: Oxford University Press, 1969), P-50

${ }^{23}$ John Burton, The Collection of the Qur'an,171

${ }^{24}$ Spencer, Did Muhammad Exist? 194

${ }^{25}$ See: Spencer Did Muhammad Exist? P-197

${ }^{26}$ Qur'ān 81:6-7

${ }^{27}$ Qur'ān 4:68

${ }^{28}$ Spencer, Did Muhammad Exist? 84, 100, P-198

${ }^{29}$ Spencer, Did Muhammad Exist?, P-103

${ }^{30}$ Azami, Studies in hadeeth Methodology and Literature, P-48

${ }^{31}$ Jamal Al-Din Zarabozo ,The authority and impotrtance of Sunna (Denver.: Al-

Basheer Pubns \& Translations, Denver.2000), P-201

${ }^{32}$ Muhammad Zubayr Siddiqi, Ahāaīth Literature. It's Origin, Development \& Special Features. (Cambridge: Islamic Texts Society, 1993) P4-5.

${ }^{33}$ Quoted by Imam Muslim in the introduction of his SahihIn the chapter entitled, "Expounding on the point that the Isnād is part of the religion"

${ }^{34}$ Quoted in Umar ibn Hasan Uthmaan al-Fullaatah, al-Widha fi al-Hadeeth (Damascus: Maktabah al-Ghazzaali, 1981), Vol.2/ P-10

${ }^{35}$ See: Muhammad Hamidullah, Sahifah Hammam ibn Munabbih (Paris: Centre Culturel Islamique, 1979), P-83

${ }^{36}$ N. Abbott, Studies In Arabic Literary Papyri, Volume II (Qur'anic Commentary \& Tradition), (The University Of Chicago Press, 1967) P-2

${ }^{37}$ Muhammad Zubayr Siddiqi, Ahāaīth Literature. It's Origin, Development \& Special Features (Cambridge: Islamic Texts Society, 1993) P-115

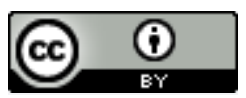

This work is licensed under a Creative Commons Attribution 4.0 International License. 